Proc. Estonian Acad. Sci. Geol., 2003, 52, 2, 87-97

\title{
Early Cambrian tubular fossils of the genus Onuphionella from Estonia
}

\author{
Kaisa Mens \\ Institute of Geology, Tallinn Technical University, Estonia pst. 7, 10143 Tallinn, Estonia \\ Received 31 July 2002, in revised form 27 February 2003

\begin{abstract}
Two forms of agglutinated tubes referable to the genus Onuphionella Kirjanov, 1968, occur in the Lower Cambrian of Estonia. The older, Onuphionella agglutinata Kirjanov, 1968, whose tubes are coated with muscovite flakes, is found in the sandy-clayey deposits of the Lontova Stage (pretrilobite Early Cambrian). The other specimen, assigned to the Onuphionella cf. durhami Signor \& McMenamin, 1988, occurs in the lowermost part of the trilobite-bearing Early Cambrian, defined as the Sorru Formation in Estonia. This form differs from O. agglutinata in the occurrence of organic matter in the tube wall and in flexible tube construction. Except Estonia, the genus Onuphionella has been reported from the Lower Cambrian of the Ukraine, Poland, and the USA.
\end{abstract}

Key words: Lower Cambrian, Estonia, body fossils, Onuphionella.

\section{INTRODUCTION}

The genus Onuphionella Kirjanov, 1968, represents enigmatic tubular wormlike fossils coated with flakes of mica like today's caddis-worm. Kirjanov (1968) assigned Onuphionella to the polychaete worms. This concept with reservation was followed by Signor \& McMenamin (1988) in their tentative assignation of Onuphionella to the phylum Annelida and class Polychaeta. The genus is represented by three species that have been reported from the Lower Cambrian of the East European Craton (Kirjanov 1968; Aren \& Lendzion 1978) and from the western North American Craton (Signor \& McMenamin 1988; Hagadorn \& Waggoner 2000).

In this paper, two mica-coated tubular fossils from the Estonian Lower Cambrian, assigned to two species of the genus Onuphionella, are discussed. The older, O. agglutinata comes from the Lontova Stage, the lowermost unit of the Lower Cambrian in Estonia, which is regarded as the pretrilobite part of the 
Cambrian succession. The younger species, assigned to $O$. cf. durhami, occurs in the Sorru Formation, regarded as the lowermost part of the trilobite-bearing Early Cambrian. Although these fossils have been reported previously (Mens \& Posti 1984; Mens \& Pirrus 1997), they have not been formally described from Estonia.

The collection of Onuphionella, deposited in the Institute of Geology at Tallinn Technical University, consists largely of samples gathered mainly in the 1970s by Erika Posti while describing drill cores. The collection is registered as TTU GI 293; the specimens figured in this article have numbers TTU GI 293135, 293-137, and 293-138.

\section{GEOLOGICAL SETTING}

The oldest Cambrian siliciclastic rocks in Estonia, assigned to the so-called pretrilobite Early Cambrian, correspond to the Platysolenites antiquissimus Zone (Mens et al. 1990; Mens \& Pirrus 1997) and possibly to the Asteridium tornatum-Comasphaeridium velvetum acritarch Zone (Moczydłowska 1991). These rocks are defined as the Lontova Stage over a large area of the East European Craton (Keller \& Rozanov 1979).

The Lontova Stage unconformably overlies stratigraphical units of different age, including those of the Precambrian crystalline basement (Mens \& Pirrus 1997). Its composition and structure reflect a transgressive-regressive accumulation during Lontova time. The stage is represented mostly by argillaceous deposits and sandstones with lateral replacement due to their distance from the coastline; lithofacies show a typical trend from nearshore to intrabasinal environments. The sandy-silty rocks prevailing in the west, considered as the Voosi Formation, grade eastwards into dominating argillaceous deposits of the Lontova Formation (Fig. 1; Kala et al. 1981). According to the ratio of rock types and their colour, these formations, in turn, are divided into seven members (Fig. 2).

The older form of Onuphionella, here assigned to O. agglutinata, occurs mainly in the Sämi Member of the Lontova Formation. In the descriptions of drill cores, the occurrence of Onuphionella sp. in the Paralepa Member of the Voosi Formation has been reported, but no material from this level is currently available.

The Sämi Member is dominated by argillaceous rocks interbedding with sandstones. Light-coloured sandstones of this member, formed during the initial phase of the Lontova transgression, are inequigranular, texturally mature, quartzose, seldom feldspathic quartzose. The argillaceous beds are prevailingly greenish-grey, with very rare small red- or lilac-coloured spots. Rock-forming sand- and silt-sized detrital minerals in diverse abundance are quartz, feldspar, and micas. Among these minerals, in sandstones quartz is predominating; in the argillaceous deposits mica flakes sometimes prevail. The mineral assemblage in the clay fraction is represented by the prevailing illite and illite-smectite with kaolinite and chlorite admixture, whereas the kaolinite content is somewhat higher than that of chlorites. 


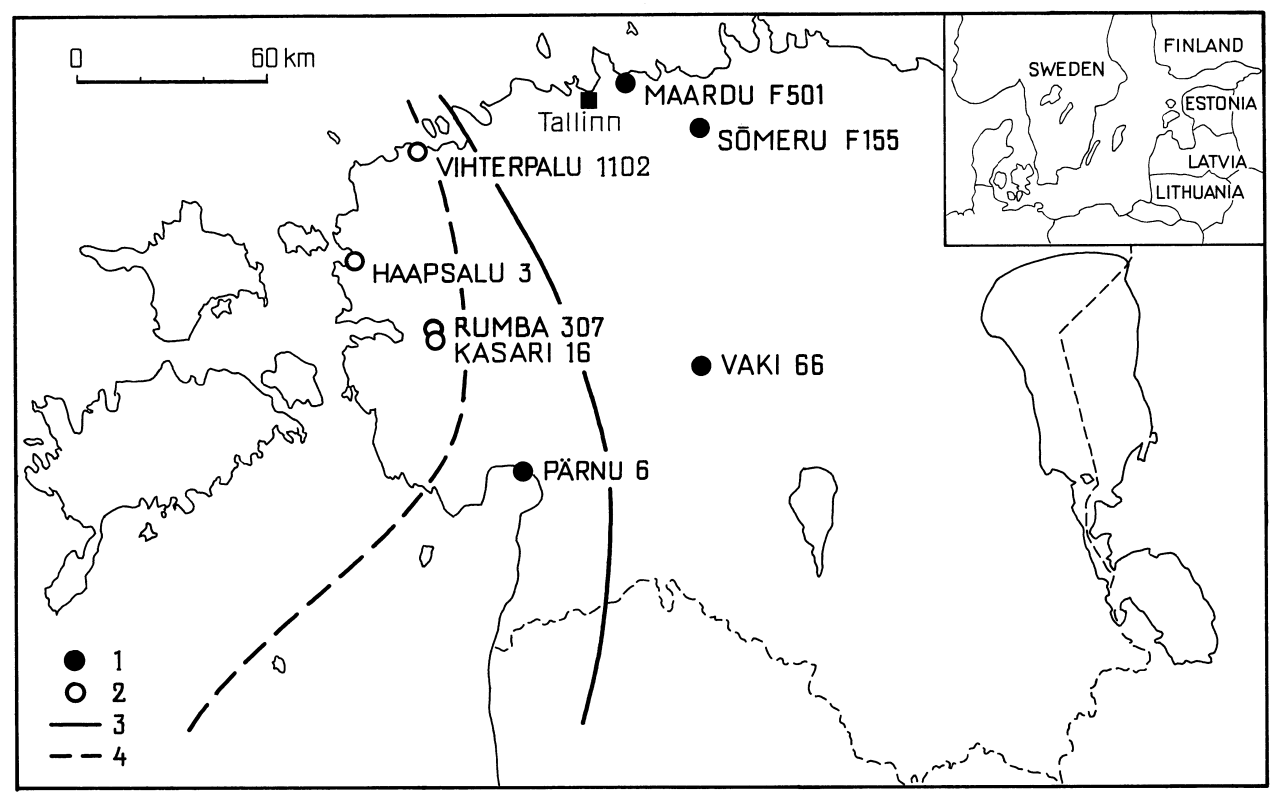

Fig. 1. Location of sections with Onuphionella finds in Estonia. 1, Onuphionella agglutinata; 2, Onuphionella cf. durhami; 3, lateral boundary between the Voosi and Lontova formations; 4 , eastern border of the present-day distribution of the Sõru deposits.

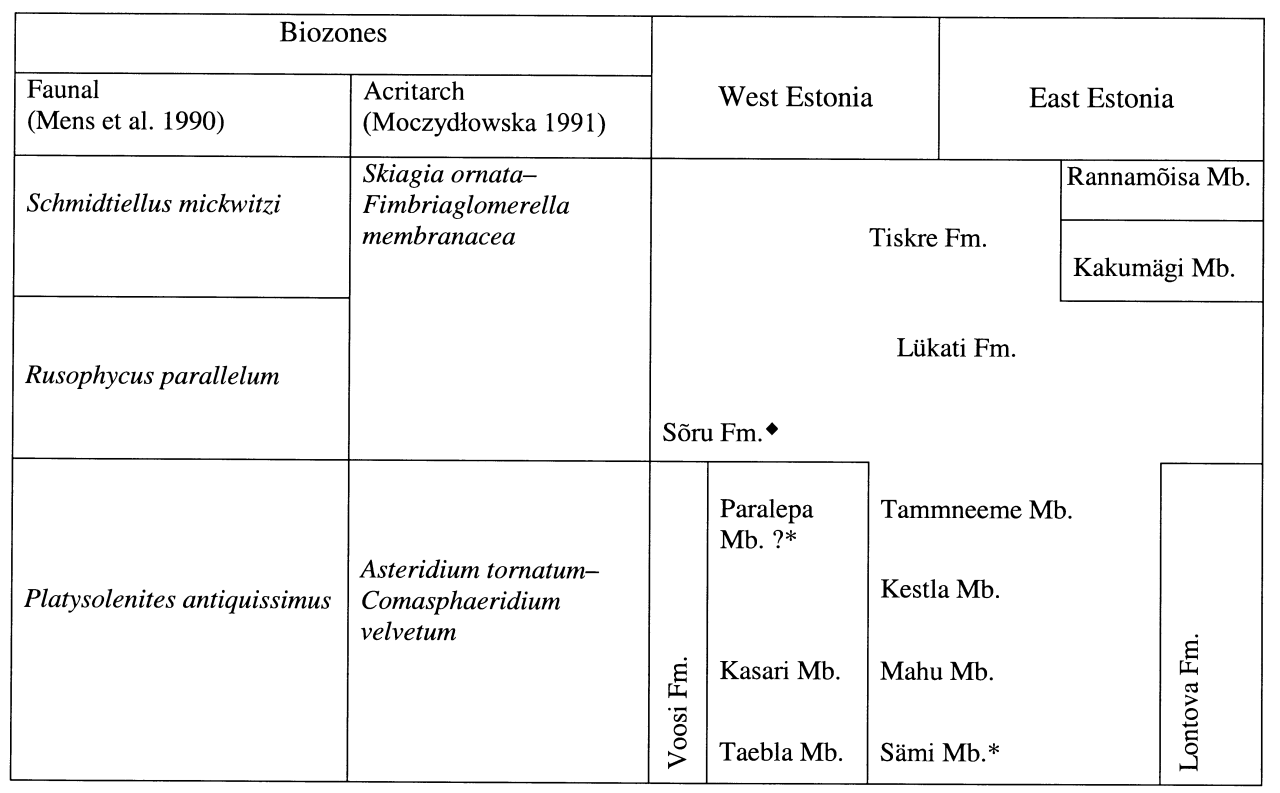

Fig. 2. Lower Cambrian stratigraphical units and occurrence of Onuphionella agglutinata $(*)$ and $O$. cf. durhami $(\bullet)$ in Estonia. 
The Lontova succession is characterized by intervals with an abundant but low-diversity fauna. The fauna is generally dominated by the species of Platysolenites and, in the lower part, also by the genus Sabelliditides. The few documented finds of the genus Aldanella (Mens \& Isakar 1999) are mainly restricted to the most clayey beds of the section (Kestla and Paralepa members). Diverse and mostly simple trace fossils are numerous in both argillaceous and sandy deposits. In addition to the index taxon, Asteridium tornatum (Volkova), the Lontova acritarch assemblage of the East European Craton is characterized by the occurrence of Granomarginata squamacea Volkova, G. prima Naumova, Tasmanites bobrowskae Ważyńska, T. tenellus Volkova, Asteridium lanatum (Volkova), and various leiosphaerids (Volkova et al. 1983). The other index taxon Comasphaeridium velvetum Moczydłowska and its accompanied species C. agglutinatum Moczydłowska, C. formosum Moczydłowska, and Pterospermella velata Moczydłowska, found in time-equivalent beds of the Lublin Slope (Moczydłowska 1991), have not been observed in the Lontova Formation of Estonia, despite the very similar palaeontological characteristics of the pretrilobite Lower Cambrian units in these areas.

The onset of the trilobite-bearing early Cambrian sediments is restricted to the westernmost marginal area of the East European Craton, where a number of longitudinal gulf-like depressions were formed. During the basin development, the sedimentation area shifted eastwards (Mens 1981).

The lower part of the Early Cambrian trilobite-bearing succession in Estonia, treated as the Liivi Group (Mens \& Pirrus 1997), comprises sediments of the Sõru, Lükati, and Tiskre formations (Fig. 2). Its lowermost unit, the Sõru Formation (Kala et al. 1984), tentatively assigned to the Rusophycus parallelum Zone, rests transgressively either on the Lontova Formation or on the Precambrian crystalline basement, and is separated by a hiatus from the underlying layers. The range of the hiatus gradually increases from west to east.

The Sorru Formation has been interpreted as shallow-water deposits, which accumulated under normal oxic conditions during the initial phase of the Liivian transgression (Mens 1981). The sedimentary structure of the Sõru Formation, as well as the character of trace fossils, suggest shallow marine depositional environments. On several levels within the formation, coarse-clastic material has been found, containing sporadic phosphatized pebbles. These texture signs indicate a low sedimentation rate, with occasional pause periods in the accumulation, regardless the poor grain size sorting and high clay content of the rocks.

In more complete sections, the lower part of the Sõru Formation consists mainly of thick-bedded, even massive, fine-grained feldspathic quartzose sandstone with thin clay interbeds and films, while the upper part is represented by a complex of rhythmically alternating thin clay-, silt-, and sandstone layers, in some places strongly bioturbated. In the western sections both rock types occur, whereas in the east only the upper part of the formation is present.

The rocks are mineralogically immature. In addition to the rock-forming quartz and feldspar, flakes of mica are very common, especially on bedding planes. Their content in the $0.1-0.05 \mathrm{~mm}$ fraction varies from less than $1 \%$ to $30 \%$, and 
even more. The majority of micaceous minerals are larger than other detrital grains, being predominantly represented by biotite, altered to a variable degree, while flakes of muscovite are subordinate. Glauconite occurs, although it is not typical of the Sõru rocks.

The Sõru Formation is a poorly fossiliferous interval and is assigned tentatively to the Rusophycus parallelum Zone by its relative stratigraphic position. In Estonia, the Sõru Formation is almost unfossiliferous: palaeontological finds are scarce and among them no biostratigraphically important fossils have been recovered. These finds are limited to long-ranging trace fossils, rare fragments of Platysolenites and agglutinated foraminifers Luekatiella (Kala et al. 1984). Acritarchs are also sparse and rather monotonous: in addition to leiosphaerids, rare Globosphaeridium cf. cerinum (Volkova), Asteridium pallidium (Volkova), Lophosphaeridium tentativum Volkova, and Tasmanites bobrowskae Ważyńska have been identified (Mens 1986).

Low biotic diversity and pauperate acritarch assemblage in deposits of the Sõru Formation reflect once again an unstable environment at the inital phase of the Liivian sedimentation.

\section{SYSTEMATIC PALAEONTOLOGY}

Phylum, class, order, and family incertae sedis Genus Onuphionella Kirjanov, 1968

1968 Onuphionella gen. n.; Kirjanov, p. 24.

1988 Onuphionella Kirjanov; Signor \& McMenamin, p. 236.

2000 Onuphionella Kirjanov; Hagadorn \& Waggoner, p. 355.

Type species. Onuphionella agglutinata Kirjanov, 1968.

Diagnosis (from Kirjanov 1968). Bright, large, straight worm-like fossils with external surface imbricated by mica flakes. Mica flakes, secured by one edge to the tube, are orientated transverse to the axis of the tube.

Species assigned. Onuphionella agglutinata Kirjanov, 1968, O. durhami Signor \& McMenamin, 1988, O. claystonensis Signor \& McMenamin, 1988.

Remarks. After finds of $O$.durhami and $O$. claystonensis the original diagnosis of Onuphionella has been supplemented with new information about the structure of the fossil. The genus Onuphionella embraces agglutinated membraneous worm-like tubes in the stiff as well in the flexible tube construction. The tubes are imbricated with different- or equal-sized mica flakes. The orientation of mica flakes is transverse or tangential to the tube axis.

Distribution. East European Craton (Estonia, Poland, the Ukraine), North American Craton (California, Nevada); Lower Cambrian. 
Systematic position. The systematic position of the genus Onuphionella is still uncertain. Specimens from the pretrilobite Lower Cambrian of the Ukraine as well as from the trilobite-bearing Lower Cambrian of Nevada have been assigned tentatively to the phylum Annelida Lamark, 1809 and class Polychaeta Grube, 1850. The Estonian material available for the study is limited. The samples are not very well preserved and do not add new information to the understanding of the systematic position of the genus.

The specimens described here are housed at the Institute of Geology at Tallinn Technical University under the registration numbers TTU GI 293-113; 293-132 to $293-138$.

\section{Onuphionella agglutinata Kirjanov, 1968}

1968 Onuphionella agglutinata sp. n.; Kirjanov, p. 24; Plate VI, fig. 1.

1978 Onuphionella agglutinata Kirjanov; Aren \& Lendzion, p. 37; Plate I, figs. 5, 6. 1984 Onuphionella agglutinata Kirjanov; Mens \& Posti, p. 7; Fig. 3.

1997 Onuphionella agglutinata Kirjanov; Mens \& Pirrus, p. 41.

Diagnosis (after Kirjanov 1968). Large, light, straight worm-like fossil coated with flakes of mica, mainly muscovite. Mica flakes are stuck to one another and orientated transverse to the tube axis. Tubes are about $4 \mathrm{~mm}$ wide, mostly laterally compressed. Only two tubes in Kirjanov's collection are cilindric and filled with deposits.

Material. Two well-preserved and two poorly preserved specimens from the Vaki 66 core (depth 359.8 m); Sõmeru F 155 core (depth 172.3 m), Maardu F 501 core (depth $114.7 \mathrm{~m}$ ), and possibly from the Pärnu 6 core (depth $462.2-469.0 \mathrm{~m}$ ). Specimens from the last site are lacking in our collection. In general, Estonian specimens are poorly preserved. A nearly complete specimen has been found only from the Vaki 66 core (TTU GI 293-138; Pl. I, fig. 1; Fig. 3).

Remarks. All specimens found in Estonia are compressed and fragmental, and their variation in length is therefore meaningless. Their width varies within 2-4 $\mathrm{mm}$ and they are usually noticeably lighter than the surrounding deposits. It is worth mentioning that the bed with Onuphionella is somewhat darker than over- and underlying layers. The specimens were found on bedding surfaces containing numerous muscovite flakes of different size, rare pyritized trace fossils, and sometimes tubes of Sabellidites.

Occurrence and stratigraphic range. Onuphionella agglutinata occurs in the western marginal area of the East European Craton. Its finds are known from the Stokhod Formation in the Ukraine (Kirjanov 1968), the Mazowize and Włodowa formations in Poland (Aren \& Lendzion 1978; Moczydłowska 1991), and the Lontova Formation in Estonia (Mens \& Posti 1984; Mens \& Pirrus 1997). According to the Cambrian correlation chart of the East European Craton (Mens et al. 1990), the majority of these finds occur in the Platysolenites antiquissimus Zone. 
PLATE I
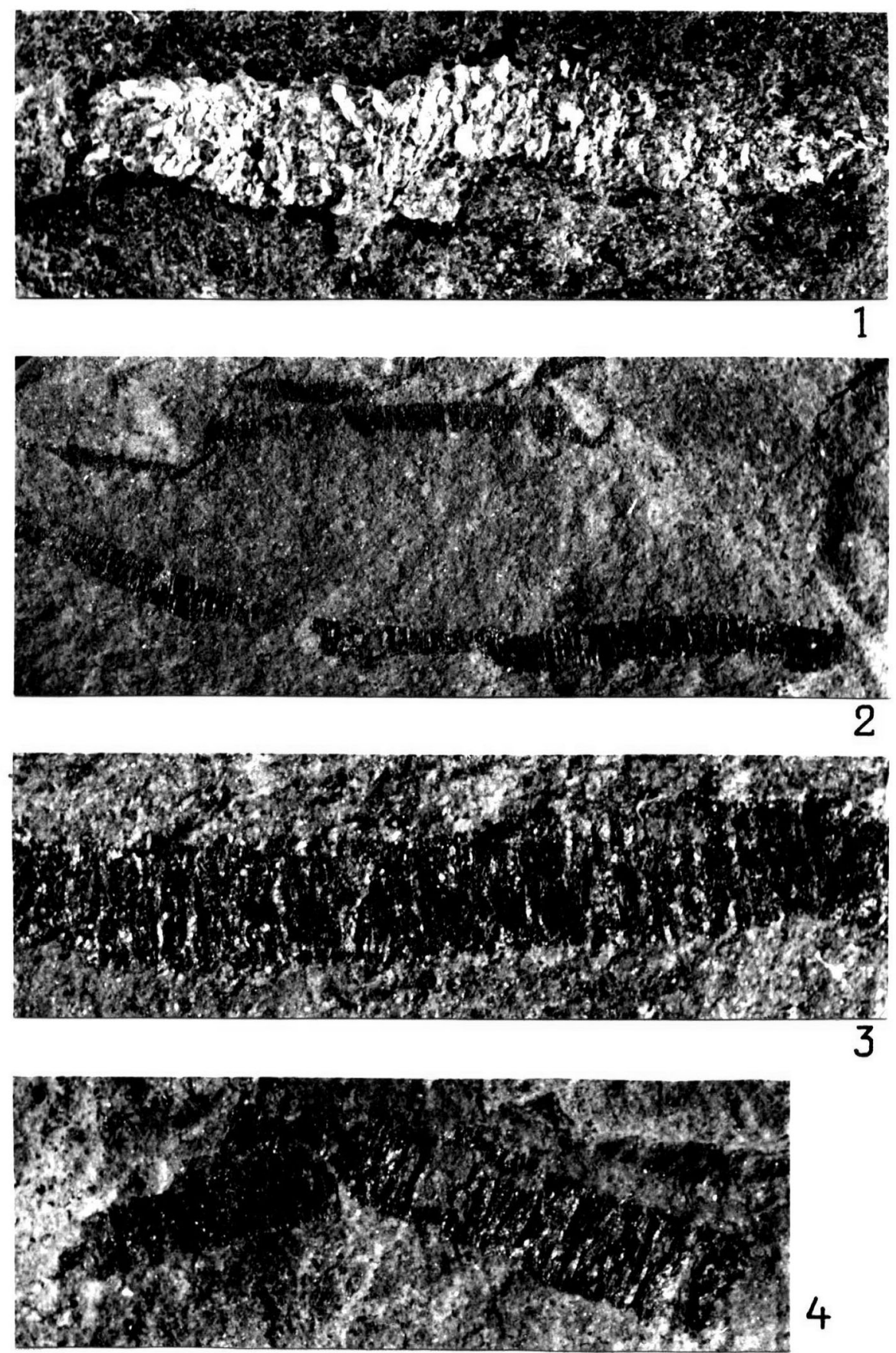

Fig. 1. Onuphionella agglutinata. TTU GI 293-138; Vaki 66 core, depth 359.8 m; Lontova Fm., Sämi Mb.; $\times 5$.

Fig. 2. Onuphionella cf. durhami. TTU GI 293-135; Kasari 16 core, depth 315.7 m; Sõru Fm.; $\times 3$.

Fig. 3. Onuphionella cf. durhami. TTU GI 293-135; Kasari 16 core, depth 315.7 m; Sõru Fm.; ×12.5.

Fig. 4. Onuphionella cf. durhami. TTU GI 293-137; Kasari 16 core, depth 319.4 m; Sõru Fm.; ×11. 

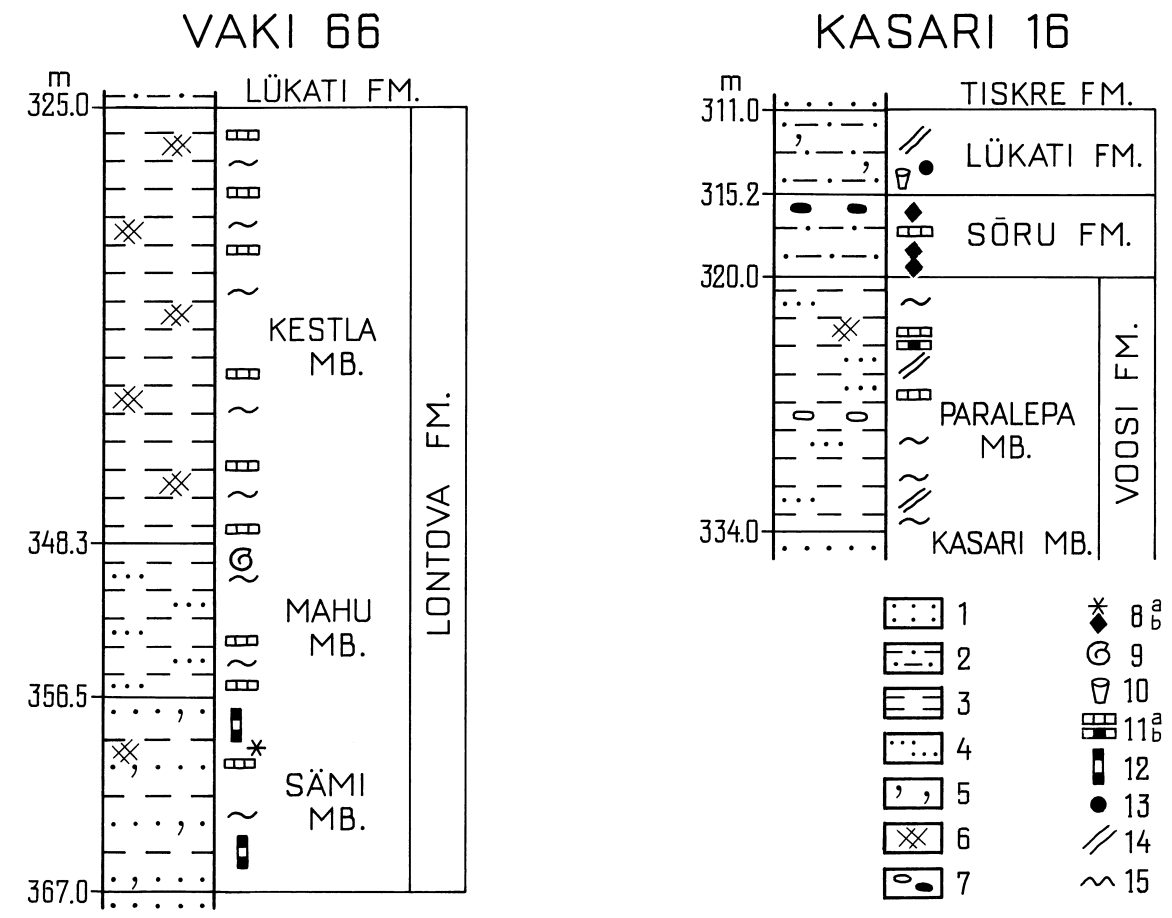

Fig. 3. Lithological log, stratigraphy, and distribution of selected fossils in the Vaki 66 and Kasari 16 cores. See Fig. 1 for location. 1, sandstone; 2, alternating sand- and claystones; 3, claystone; 4, lenses of sandstone; 5 , glauconite; 6 , variegated deposits; 7, pebbles. Fossil occurrences: 8, Onuphionella: a) O. agglutinata, b) O. cf. durhami; 9, Aldanella kunda; 10, Volborthella sp.; 11, Platysolenites: a) P. antiquissimus, b) P. spiralis; 12, Sabellidites sp.; 13, Lükati acritarch assemblage (see the text); 14 , ichnites filled with sandy material; 15 , pyritized ichnites.

Only in southeastern Poland O. agglutinata is also found from the upper part of the Sabellidites cambriensis Zone (Aren \& Lendzion 1978; Moczydłowska 1991).

Onuphionella cf. durhami Signor \& McMenamin, 1988

Plate I, figures 2-4

1988 Onuphionella durhami sp. n.; Signor \& McMenamin, p. 237; Fig. 3 (1-5)

Diagnosis (after Signor \& McMenamin 1988, abbreviated). Tubular flattened fossil whose width varies from 3.7 to $7.1 \mathrm{~mm}$, with weak annulation characterized by the agglutinated construction. The fossil is represented by flexible membraneous organic tubes ornamented with muscovite flakes equal in size, arrayed in irregular rows transverse to the tube axis. Flakes lie flat on the tube surface, partially overlying the adjacent flakes. 
Material. Twenty-one fragments from the Kasari 16 core (depth 315.2-319.4 m); eight fragments from the Rumba 307 core (depth $305.2 \mathrm{~m}$ ); six fragments from the Haapsalu 3 core (depth $217 \mathrm{~m}$ ); three fragments from the Vihterpalu 1102 core (depth 91.5-96.5 m). Figured specimens: TTU GI 293-135; Pl. I, figs. 2-3 and TTU GI 293-137; Pl. I, fig. 4.

Description. The specimens, considered here as $O$. cf. durhami, occur in the form of thin films on the greenish-grey surface of argillaceous deposits. The fossil is darker than the background, due to the occurrence of organic matter and altered biotite in its composition. They are distinctive, randomly curved, weakly annulated tubes with stripy, tightly arranged, altered biotite flakes in transverse rows (Pl. I, figs. 2-4). The tubes are usually broken at both ends, and are laterally compressed. The width of fragments in our collection varies from 0.1 to $4 \mathrm{~mm}$.

At first glance, judging by the morphology, size, and pattern of the occurrence, $O$. cf. durhami has some resemblance to Sabellidites. The latter, however, lacks the ornament of mica flakes.

Remarks. The Sõru fossil has a striking resemblance to the $O$. durhami described from the Lower Cambrian Campito Formation of California (Signor \& McMenamin 1988) that was situated in the southwestern part of the Great Basin at that time. Similarities include overall shape, size, flexibility of the test, and mica coating in the composition of the test wall. The Onuphionella from the Sorru Formation differs from the holotype, as well as from its paratypes in California in its imbrication of altered biotite instead of muscovite. Also, the size of individual mica flakes on the holotype of $O$. durhami averages $0.5 \mathrm{~mm}$, which means that they are substantially larger than the flakes on the Sorru specimen $(0.2-0.3 \mathrm{~mm})$.

Occurrence and stratigraphic range. Onuphionella durhami is known from the North American Craton and $O$. cf durhami from the northwestern marginal area of the East European Craton. It is highly probable that the differences in the mica composition and in size of their flakes are close to depositional material. Stratigraphically, the Sõru Formation yielding $O$. cf. durhami conventionally belongs to the Rusophycus parallelum Zone (Mens et al. 1990). The upper part of the Campito Formation belongs to the Fallotaspis Zone (Signor \& McMenamin 1988) and the lower part yields trilobite trace fossils.

Although precise intercratonic correlation is lacking, both fossils are connected with the first sedimentary stage of the trilobite-bearing Early Cambrian accumulation. Besides, both stratigraphic units are characterized by co-occurrence of $O$. durhami (or $O$. cf. durhami) and Platysolenites antiquissimus: these finds are linked to the onset of the trilobite-bearing Early Cambrian accumulation.

\section{CONCLUSIONS}

The genus Onuphionella occurs in the siliciclastic or predominantly siliciclastic successions of the lowermost Lower Cambrian. The finds are particularly valuable because they come from two far-situated areas - the East European and 
North American cratons. According to the faunal records (acritarchs, trilobites, trace fossils) of the former area, the older species, O. agglutinata, is closely tied to the pretrilobite Lower Cambrian deposits, whereas the first appearance of $O$. durhami and $O$. cf. durhami occurred at the same time with trilobites (or, at least, their traces). This observation is in agreement with the acritarch record (numerous species of Skiagia, Globosphaeridium, etc. appear). Establishing the stratigraphic range of both species would allow a more precise stratigraphic correlation of the lowermost Lower Cambrian rocks between East European and North Americam cratons.

Discussing taphonomy and depositional environment of Onuphionella, Signor \& McMenamin (1988) interpet their finds in the Campito Formation as stormtransported tubes buried at a considerable distance from the living area. Unlike the mineral composition of the Campito Formation, mica flakes are very common in the Lower Cambrian siliciclastic deposits of the East European Craton, including the Lontova and Sõru formations in Estonia. It seems as if in sedimentary basins of the East European Craton, Onuphionella, together with other soft-bodied organisms living at the time of fair weather conditions at the seafloor or in a benthic bed, have been buried during the intense supply of clastogenic material. This is supported by the fact that relatively fragile tubes are found in varigrained clastogenic sediments without considerable damage.

\section{ACKNOWLEDGEMENTS}

This study was carried out in the Institute of Geology at Tallinn Technical University and was supported by research grant No. 4674 from the Estonian Science Foundation.

The author is thankful to Acad. Dimitri Kaljo and Dr. Ivar Puura for the constructive reviews, critical remarks, and useful comments on the manuscript, Kaie Ronk for the drawings, Helle Pohl for linguistic improvements, and Gennadi Baranov for the photographic work. Special thanks go to Erika Posti for her assistance in field work and for collecting the specimens of Onuphionella.

\section{REFERENCES}

Aren, B. \& Lendzion, K. 1978. Stratigraphic-lithological characteristics of the Vendian and Lower Cambrian. Prace Instytutu Geol., 90, 7-49.

Hagadorn, J. W. \& Waggoner, B. 2000. Ediacaran fossils from the southwestern Great Basin, United States. J. Paleontol., 74, 349-359.

Kala, E., Kajak, K., Mens, K. \& Pirrus, E. 1981. Lithostratigraphy and facies of the Lontova Stage in Estonia. ENSV TA Toim. Geol., 30, 137-147 (in Russian).

Kala, E. A., Mens, K. A. \& Pirrus, E. A. 1984. On the stratigraphy of the Cambrian in West Estonia. In Stratigrafiya drevnepaleozojskikh otlozhenij Pribaltiki (Männil, R. \& Mens, K., eds.), pp. 18-37. Inst. Geol. Akad. Nauk ESSR, Tallinn (in Russian). 
Keller, B. M. \& Rozanov, A. Yu. (eds.). 1979. Upper Precambrian and Cambrian Stratigraphy of the Western Part of the East European Platform. Nauka, Moscow (in Russian).

Kirjanov, V. V. 1968. Palaeontological remains and stratigraphy of the Baltic Group deposits in Volynia-Podolia. In Paleontologiya i stratigrafiya nizhnego paleozoya Volyno-Podolii (Shulga, B. L., ed.), pp. 5-25. Naukova Dumka, Kiev (in Russian).

Mens, K. A. 1981. On the Early Cambrian sedimentation stages in the East Baltic area. Izv. Akad. Nauk SSSR, Ser. Geol., 3, 82-90 (in Russian).

Mens, K. 1986. Detailing of the Lower Cambrian stratigraphical scheme for the East European Platform. In Vendian and Cambrian Facies and Stratigraphy of the Western Part of East European Platform (Pirrus, E. A., ed.), pp. 138-151. Acad. Sci. ESSR, Inst. Geol., Tallinn (in Russian).

Mens, K. \& Isakar, M. 1999. Facies distribution of Early Cambrian molluses in Estonia. Proc. Estonian Acad. Sci. Geol., 43, 110-115.

Mens, K. \& Pirrus, E. 1997. Cambrian. In Geology and Mineral Resources of Estonia (Raukas, A. \& Teedumäe, A., eds.), pp. 35-51. Estonian Academy Publishers, Tallinn.

Mens, K. \& Posti, E. 1984. Distribution and correlation significance of organic remains in the Baltic Series of Estonia. In Stratigrafiya drevnepaleozojskikh otlozhenij Pribaltiki (Männil, R. \& Mens, K., eds.), pp. 5-17. Inst. Geol. Akad. Nauk ESSR, Tallinn (in Russian).

Mens, K., Bergström, J. \& Lendzion, K. 1990. The Cambrian System on the East European Platform; correlation chart and explanatory notes. IU Geol. Sci. Publ., 25.

Moczydłowska, M. 1991. Acritarch biostratigraphy of the Lower Cambrian and PrecambrianCambrian boundary in southeastern Poland. Fossils Strata, 29.

Signor, P. W. \& McMenamin, M. A. S. 1988. The Early Cambrian worm tube Onuphionella from California and Nevada. J. Paleontol., 62, 233-240.

Volkova, N. A., Kirjanov, V. V., Piscun, L. N., Paškevičiene, L. T. \& Jankauskas, T. N. 1983. Plant microfossils. In Upper Precambrian and Cambrian Paleontology of East European Platform (Urbanek, A. \& Rozanov, A. Yu., eds.), pp. 7-46. Wydawnictwa Geologiczne, Warszawa.

\section{Perekonna Onuphionella torujad kivistised Eesti Alam-Kambriumist}

\section{Kaisa Mens}

Vilgulehtedega kaetud ussikujulised, väliselt puruvana meenutavad kivistised perekonnast Onuphionella on senini teada Ida-Euroopa ja Põhja-Ameerika läbilõigete Alam-Kambriumi klastogeensetes setendites.

Eesti läbilõigetes on sellest perekonnast esindatud kaks liiki. Vanema $O$. agglutinata - leiud on seotud Lontova kihistuga, kuna noorem - O. cf. durhami - iseloomustab Sõru kihistut.

Onuphionella seotus kihipindadega ning kivimi ja torukesta moodustavate vilkude samasus lubab oletada, et need organismid elasid merepõhjas klastogeense materjali juurdevoolu puudumise ajal. Purdmaterjali suurenenud sissevool mattis nad kohapeal või nihutas vaid veidi elukohast eemale. 